\title{
Determinants of caesarean birth on maternal demand in the Islamic Republic of Iran: a review
}

Fatemeh Darsareh ${ }^{1}$, Teamur Aghamolaei ${ }^{1}$, Minoo Rajaei ${ }^{2}$ and Abdoulhossain Madani ${ }^{1}$

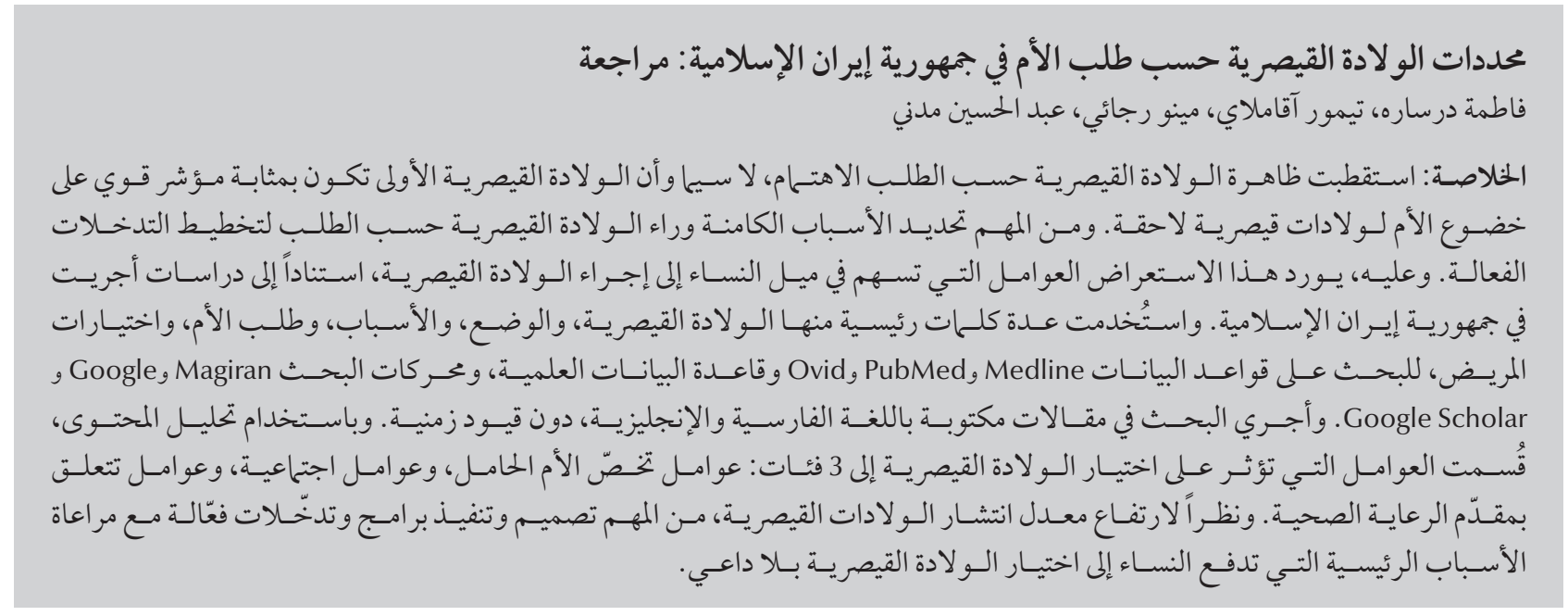

ABSTRACT The phenomenon of caesarean birth on demand has gained attention, particularly as a first caesarean birth appears to be strongly predictive of subsequent caesareans. Identification of reasons behind caesarean birth on demand is important for planning effective interventions. Therefore, this review reports the factors involved in the tendency of women to undergo caesarean birth, based on studies in the Islamic Republic of Iran. Several keywords including caesarean delivery, childbirth, causes, maternal request/demand, and patient choice were used to search Medline, PubMed, Ovid, Scientific Information Database, Magiran, Google and Google Scholar. The search was conducted on Persian and English language articles, with no time limitation. Using content analysis, the factors influencing caesarean section were divided into 3 categories: maternal, social and healthcare giver. According to the high prevalence of caesarean section, it is important to design and implement effective programmes and interventions with consideration of the key reasons that lead women to opt for unnecessary caesarean section.

\section{Analyse des déterminants des naissances par césarienne sur demande de la mère en République islamique d'Iran}

RÉSUMÉ Le phénomène des naissances par césarienne sur demande fait l'objet de discussions, notamment parce qu'une première césarienne est hautement prédictive d'autres césariennes lors des naissances suivantes. L'identification des raisons d'un accouchement par césarienne sur demande est importante de façon à planifier des interventions efficaces. À ce titre, la présente analyse fait état, sur la base d'études menées en République islamique d'Iran, des facteurs impliqués dans la tendance qu'ont les femmes de recourir à un accouchement par césarienne. Plusieurs mots clés incluant «naissance par césarienne », « accouchement », « causes », « demande/ exigence de la mère », ainsi que «choix de la patiente» ont été utilisés pour effectuer des recherches dans Medline, PubMed, Ovid, Scientific Information Database, Magiran, Google et Google Scholar. La recherche a été menée à partir d'articles en persan et en anglais, sans limitation de temps. À l'aide d'une analyse de contenu, les facteurs influençant le recours à une césarienne ont été divisés en trois catégories : les facteurs liés à la mère, les facteurs sociaux, et ceux liés aux dispensateurs de soins. Eu égard à la prévalence élevée de césariennes, il est important de concevoir et de mettre en ouvre des programmes et des interventions efficaces prenant en compte les raisons principales qui conduisent les femmes à opter pour une césarienne non nécessaire. 


\section{Introduction}

Caesarean section rates are on the rise worldwide (1). Based on a recent study in the Islamic Republic of Iran, the rate of caesarean section is $49 \%$ nationwide (2). Caesarean birth on maternal demand (CBMD) is responsible for some increase in the overall rate. In developed countries, conservative estimates of CBMD range from $4 \%$ to $18 \%$ of all caesarean deliveries (3). Although the rate of CBMD in the Islamic Republic of Iran remains unclear because of poor documentation, the total rate of caesarean birth is unfortunately high (4). CBMD is defined as elective caesarean delivery for singleton pregnancy on maternal request at term in the absence of any medical or obstetric indications (5). It is now recognized that performing a caesarean section with no medical indication offers no health advantages for the mother and infant, and has increased health risks, from both physical and emotional perspectives, compared to vaginal birth (6).

The problem is that caesarean birth is associated with an increase in maternal and infant mortality and morbidity, and increased healthcare costs. Theoretically, maternal outcomes of fever, infection, pneumonia and thromboembolism are consistently increased with medically indicated caesarean birth and would also be present in instances of CBMD (7). The issue of cost must also be considered in the broader context of burden to the already stressed healthcare system and the impact on finite resources (6).

CBMD has received increasing attention in the social science literature, with a focus on women's motivations. The reasons for CBMD are complex and it appears to have interrelated factors that are not easily explained. As the literature review revealed, elective caesarean section is related to personal, psychological and social factors such as autonomy, self-control, perceptions of safety, fear of childbirth, sexuality, and perceived quality of obstetric care (8). Limited information is available about how the decision for elective caesarean section comes about in the clinical environment $(9,10)$. CBMD is clinically relevant because of the increasing numbers of women choosing this mode of delivery, the health risks to the mother and infant, and the increased cost associated with the procedure.

There is a need to gather information about the factors involved in the tendency of women to opt for caesarean section, based on studies that have been conducted in the Islamic Republic of Iran. The ultimate goal is to devise interventions to reduce the number of maternal requests for caesarean sections, thereby reducing their associated mortality, morbidity and healthcare costs. Many studies have investigated the reasons for CBMD in the Islamic Republic of Iran. However, these studies have been in a particular geographical area. Hence, there is a need to identify and summarize the different causes in different regions of the country, and the results could be used to design and implement appropriate national plans and interventions to reduce unnecessary caesarean sections.

\section{Methods}

This study was a review of the literature regarding elective caesarean birth without specific medical indications. We searched the following databases: Medline, PubMed, Ovid, Google and Google Scholar. To access Iranian studies published in Persian, we also searched Scientific Information Database, Iran Medex and Magiran. We searched using the terms caesarean delivery, childbirth and birth, maternal request/demand, and patient choice for published articles in Persian and English languages, with no time limit. We reviewed articles from all over the Islamic Republic of Iran because of the ethnic and cultural diversity in the country.
Approximately 126 articles were initially obtained including abstracts, quantitative and qualitative research, governmental reports, comprehensive reviews, and opinion/editorial articles. We restricted the search to peerreviewed full-text articles that explained only CBMD without any medical indications. After excluding irrelevant or repeated articles, experimental and quasi-experimental studies, we analysed 29 articles (24 quantitative and 5 qualitative) related to the objectives of the study. All studies were performed from 2002 to 2014. Selected articles were studied extensively to extract the required information (Figure 1) and we identified the factors influencing the decision for caesarean section.

\section{Results}

Several factors influenced women to opt for caesarean birth, which can be divided into 3 groups: maternal, social and healthcare provider. Maternal factors included demographic factors such as age, education, job status and place of living; psychological factors such as fear and anxiety; and other factors such as perception and attitude toward childbirth that was mostly related to individual behaviour and comprehension. The reviewed studies showed that factors influencing women to choose caesarean section included advanced maternal age, high educational level, living in the city, fear of vaginal birth pain, concerns about infant safety, fear of urogenital trauma during vaginal birth, and prior complicated normal childbirth.

The second group were social factors. In some cases CBMD was based on the recommendation of family and friends. Social status was also an influencing factor and women with higher social status were more likely to have an elective caesarean birth.

The third group were healthcare provider factors. Recommendations 
from obstetricians and midwives were the main reasons behind CBMD in some cases. The results are summarized in Table 1.

\section{Discussion}

Historically, the management of pregnancy and labour has been primarily associated with high expectation, and until recently, the concept of requesting a caesarean birth was not recognized as a possibility for women. To request a caesarean section is a difficult decision for women planning childbirth, and according to previous studies, too many factors are involved in this decisionmaking process. The aim of this review was to identify the main factors behind this increased tendency of women to request a caesarean section in the Islamic Republic of Iran. We found that CBMD was influenced by maternal, social and healthcare giver factors.

\section{Maternal factors}

Caesarean section among older women (>35 years old) is more frequent than in younger women (11-13). Consistent research findings indicate that women who choose elective caesarean tend to be older (14). Maternal age has been reported as an independent risk factor for caesarean delivery. The reasons for this increased risk remain unclear, but other studies have suggested that it may be due to physician and patient concern over pregnancy outcomes in older women (15). Advanced maternal age places women in a risk category in which screening and diagnostic tests for chromosomal abnormalities are routinely offered and is associated with infertility and assisted reproductive technology (16). These factors may contribute to a maternal viewpoint of the pregnancy as being high risk and requiring additional medical intervention, which leads to elective caesarean section (17).
Caesarean section among women with higher education is more frequent than among those with lower education $(11,12,18)$. This is consistent with some studies that have reported an increased tendency for caesarean section among women with higher educational level (19) but inconsistent with other reports that more educated women choose vaginal delivery (20). Although some studies have indicated that women who live in a city and who are in employment are more likely to choose caesarean section $(13,21,22)$, these factors have less effect than other demographic factors on choosing caesarean section.

Psychological factors, especially fear of vaginal birth and its associated pain, are related to the demand for caesarean birth (23-32). Anxiety and fear of childbirth have consistently been associated with maternal request for elective caesarean section (33-36). Severe fear of childbirth can lead to pregnancy complications (37), which is thought to increase the percentage of women who demand elective caesarean birth. Hofberg and Brockington described a condition known as tokophobia, a fear of death in childbirth, preceding pregnancy (38). Women with this condition are afraid that they will die if they give birth vaginally. It is reported that about half of women with tokophobia choose an elective caesarean section (38). The emotional status of women during pregnancy and delivery may be associated with interpretation, expectations and decisions concerning the delivery process. Pregnancy-related depression, stress or anxiety may contribute to lessened confidence, fear and dissatisfaction with the birthing process (39), which can encourage women to opt for caesarean section.

Another important factor is negative past experiences - both with regard to pregnancy and childbirth - and this is currently considered to be one of the main causes of fear of childbirth that might lead to elective caesarean section $(12,23,28,40)$. Women who have had a negative previous birth experience continue to feel fear in subsequent births, especially in relation to labour pain. Labour pain is one of the most stressful episodes in childbirth (41) and a significant association with elective caesarean section has been reported $(34,42)$.

Almost all pregnant women are concerned about the well-being of the fetus and want to provide a safe uterine environment. They desire a type of birth that is safe for the infant. Although there is no evidence to support that caesarean birth with no medical indication offers health advantages for the mother and infant, many women believe that elective caesarean section is safer for the fetus (6). Concerns about fetal safety have been reported in different qualitative studies as a reason for CBMD (43-48).

Many women are concerned about retaining function of their urogenital organs after childbirth. Although there is no consensus that planned caesarean birth preserves the pelvic floor or prevents urinary incontinence or anorectal dysfunction, some women are afraid that having vaginal birth will damage these internal organs $(23,24,39)$.

One study has indicated that some women tend to elective caesarean section because they want their baby to be born on a particular day (27). Studies in Australia and Turkey have suggested that women may opt for caesarean delivery because they can plan for the time of day or week that meets the needs of the obstetricians' and their own schedules $(49,50)$. This practice is more common in private health care where women have more flexibility and financial strength to schedule delivery.

\section{Social factors}

The support of family and friends is associated with CBMD $(24,26,27)$. Sharing childbirth experiences within the family may affect a woman's decision about the method of birth. Women who benefit from the support of family and friends take a more active role in the 


\begin{tabular}{|c|c|c|c|}
\hline Authors & Type of research & Participants & Results \\
\hline Aram et al. (2002) (22) & Cross-sectional & 500 parturients & $\begin{array}{l}\text { Fearing vaginal delivery pain, doctor's recommendation, } \\
\text { concern about infant health and mother's fitness, associated } \\
\text { disease, high educational level, having job were associated } \\
\text { with caesarean section. }\end{array}$ \\
\hline $\begin{array}{l}\text { Shareat et al. (2002) } \\
(67)\end{array}$ & Cross-sectional & 824 parturients & $\begin{array}{l}13.5 \% \text { of caesarean sections were due to fear of vaginal } \\
\text { delivery pain, or doctor's recommendation. }\end{array}$ \\
\hline $\begin{array}{l}\text { Alimohamadian et al. } \\
(2003)(62)\end{array}$ & Cross-sectional & 824 parturients & $\begin{array}{l}\text { Mother's request or doctor's recommendation was the main } \\
\text { reason for caesarean section. }\end{array}$ \\
\hline Moradan (2004) (37) & Cross-sectional & 400 pregnant women & $\begin{array}{l}\text { The most common cause of tendency to caesarean section } \\
\text { was fear from pain during vaginal delivery. }\end{array}$ \\
\hline $\begin{array}{l}\text { Mobaraki et al. (2005) } \\
\text { (59) }\end{array}$ & Cross-sectional & 7649 parturients & $\begin{array}{l}\text { Doctor's recommendation, fear of vaginal delivery pain, } \\
\text { and mother's request were the factors leading to elective } \\
\text { caesarean section. }\end{array}$ \\
\hline $\begin{array}{l}\text { Mohammad et al. } \\
(2006)(13)\end{array}$ & Cross-sectional & 1473 parturients & $\begin{array}{l}\text { Older age of women, higher level of education, higher } \\
\text { socioeconomic status and hospitalization in private hospitals } \\
\text { were associated with caesarean section. }\end{array}$ \\
\hline $\begin{array}{l}\text { Khosrovi et al. (2006) } \\
(55)\end{array}$ & Cross-sectional & 473 parturients & $\begin{array}{l}\text { Caesarean section was more common in women with a } \\
\text { better job, higher educational level and living in a city. }\end{array}$ \\
\hline $\begin{array}{l}\text { Seyed Noori et al. } \\
(2006)(46)\end{array}$ & Cross-sectional & 210 pregnant women & $\begin{array}{l}\text { Infant health, fear of vaginal delivery pain, mother's safety, } \\
\text { infant's safety, and friend's recommendation were the main } \\
\text { factors leading to elective caesarean section. }\end{array}$ \\
\hline $\begin{array}{l}\text { Negahban et al. (2006) } \\
(27)\end{array}$ & Cross-sectional & 256 pregnant women & $\begin{array}{l}\text { Fearing vaginal delivery pain, tube ligation, fearing infant's } \\
\text { harm, fearing harm to female reproductive system, maternal } \\
\text { health, views of partner and family, and living in a city were } \\
\text { the factors associated with caesarean section. }\end{array}$ \\
\hline $\begin{array}{l}\text { Tabande \& Kashani } \\
(2007)(40)\end{array}$ & Cross-sectional & 187 pregnant women & $\begin{array}{l}\text { Low pain, fearing harm to female reproductive system, } \\
\text { concern about infant safety, medical condition, and negative } \\
\text { experience from previous childbirth were the factors leading } \\
\text { to elective caesarean section. }\end{array}$ \\
\hline $\begin{array}{l}\text { Mohammaditabar et } \\
\text { al. }(2009)(30)\end{array}$ & Cross-sectional & 618 primiparous & $\begin{array}{l}\text { Fear of labour pain and medical staff play a role in high } \\
\text { caesarean section rate. }\end{array}$ \\
\hline $\begin{array}{l}\text { Mohammad et al. } \\
\text { (2009) (58) }\end{array}$ & Cross-sectional & 250 pregnant women & $\begin{array}{l}\text { Doctor's recommendation, fearing vaginal delivery pain, } \\
\text { previous caesarean section, and care given by private } \\
\text { physician were the main factors leading to elective caesarean } \\
\text { section. }\end{array}$ \\
\hline Alavije et al. (2010) (32) & Cross-sectional & 342 parturients & $\begin{array}{l}\text { Lower pain, infant's health, maternal health and friends' } \\
\text { opinion were associated with elective caesarean section. }\end{array}$ \\
\hline $\begin{array}{l}\text { Sharghi et al. (2010) } \\
(60)\end{array}$ & Cohort study & 396 pregnant women & $\begin{array}{l}\text { Caesarean section was chosen as the most popular method } \\
\text { for delivery. The most effective factor in decision-making was } \\
\text { physician's suggestion. }\end{array}$ \\
\hline $\begin{array}{l}\text { Atghaei \& Nouhi } \\
\text { (2010) (29) }\end{array}$ & Cross-sectional & 400 pregnant women & $\begin{array}{l}\text { Fear of vaginal delivery pain was the main factor for elective } \\
\text { caesarean section. }\end{array}$ \\
\hline $\begin{array}{l}\text { Fathian et al. } \\
(2010)(57)\end{array}$ & Cross-sectional & 195 parturients & $\begin{array}{l}\text { Doctor's persistence, personal belief and mother's } \\
\text { persistence were the factors leading to elective caesarean } \\
\text { section. }\end{array}$ \\
\hline $\begin{array}{l}\text { Bahonar et al. (2010) } \\
\text { (18) }\end{array}$ & Case-control & 210 parturients & $\begin{array}{l}\text { High educational level and family recommendation were } \\
\text { associated with elective caesarean section. }\end{array}$ \\
\hline Naseh et al. (2010) (12) & Cross-sectional & 1500 parturients & $\begin{array}{l}\text { Old age and education, and previous delivery experience } \\
\text { were associated with elective caesarean section. }\end{array}$ \\
\hline Moeini et al. (2011) (44) & Cross-sectional & 346 pregnant women & $\begin{array}{l}\text { Doctor's opinion, low pain, infant's safety, awareness of } \\
\text { delivery time, and partner's suggestion were the factors } \\
\text { leading to elective caesarean section. }\end{array}$ \\
\hline $\begin{array}{l}\text { Ghooshchian et al. } \\
(2011)(28)\end{array}$ & $\begin{array}{l}\text { Descriptive- } \\
\text { analytical }\end{array}$ & 300 pregnant women & $\begin{array}{l}\text { Fearing vaginal delivery pain, advanced age, and negative } \\
\text { previous childbirth experience led to elective caesarean } \\
\text { section. }\end{array}$ \\
\hline
\end{tabular}




\begin{tabular}{|c|c|c|c|}
\hline Authors & Type of research & Participants & Results \\
\hline $\begin{array}{l}\text { Bagheri et al. } \\
(2012)(45)\end{array}$ & Qualitative study & 11 pregnant women & $\begin{array}{l}\text { Fearing vaginal delivery pain led to elective caesarean } \\
\text { section. }\end{array}$ \\
\hline $\begin{array}{l}\text { Movahed et al. (2012) } \\
\text { (11) }\end{array}$ & Cross-sectional & 600 pregnant women & $\begin{array}{l}\text { Significant relation among these factors (age, age at marriage, } \\
\text { education, spouse's education, occupational status, place } \\
\text { of birth, social status, previous childbirth method, record of } \\
\text { barrenness, place of previous childbirth, place of pregnancy } \\
\text { care, record of caesarean in family and attitude toward } \\
\text { caesarean (with choice of caesarean having been approved. }\end{array}$ \\
\hline $\begin{array}{l}\text { Shahraki Sanavi et al. } \\
(2012)(27)\end{array}$ & Qualitative study & $\begin{array}{l}200 \text { pregnant women } \\
\text { in third trimester }\end{array}$ & $\begin{array}{l}\text { Fear of pain, inability to withstand vaginal childbirth pain, } \\
\text { encouragement from family members, partner's and } \\
\text { physician's confidence about the infant's safety, and earlier } \\
\text { preparation knowledge of exact time of delivery were the } \\
\text { main reasons to have elective caesarean section. }\end{array}$ \\
\hline $\begin{array}{l}\text { Davari et al. } \\
\text { (2012) (54) }\end{array}$ & Cross-sectional & $\begin{array}{l}459 \text { Nulliparous } \\
\text { women }\end{array}$ & $\begin{array}{l}\text { High educational level and social status were associated with } \\
\text { elective caesarean section. }\end{array}$ \\
\hline $\begin{array}{l}\text { Abbaspoor et al. } \\
(2014)(25)\end{array}$ & Qualitative study & $\begin{array}{l}18 \text { pregnant and } \\
\text { postnatal women }\end{array}$ & $\begin{array}{l}\text { Fear of normal childbirth process and concern about normal } \\
\text { delivery complications resulted in most participants deciding } \\
\text { to have caesarean section. }\end{array}$ \\
\hline $\begin{array}{l}\text { Akbari \& Ahmadi } \\
(2014)(24)\end{array}$ & Cross-sectional & $\begin{array}{l}200 \text { primiparous } \\
\text { women }\end{array}$ & $\begin{array}{l}\text { Major reasons declared by mothers in the caesarean group } \\
\text { were fear of vaginal delivery pain, concerns about vaginal } \\
\text { delivery complications, and recommendation of friends and } \\
\text { their delivery method. }\end{array}$ \\
\hline Faisal et al. (2014) (23) & Qualitative study & 14 primigravidae & $\begin{array}{l}\text { Reasons for requesting a caesarean section were related to } \\
\text { fear of childbirth (labour pain, injury to mother or infant), } \\
\text { complications after vaginal delivery (vaginal prolapse, urinary } \\
\text { incontinence or sexual dysfunction), trust in obstetricians, } \\
\text { and lack of trust in maternity ward staff. }\end{array}$ \\
\hline
\end{tabular}

birth process, and women without such support are more fatalistic about their role in the birth process (51). Some research has shown that women who receive social support in pregnancy and during labour have lower rates of caesarean section (52).

Another social factor that might influence the type of birth decision is social status. Some studies have suggested that caesarean sections are more likely in women of higher social status (53). In contrast, one retrospective study of a large number of caesarean sections in England stratified by social status found that caesarean sections were not more likely in women of higher social status (54).

\section{Healthcare provider factors}

Recommendation by physicians and midwives is one of the main reasons for caesarean section (4,55-61).
Traditionally, the role of obstetricians has been paternalistic, and women have complied with their recommendations based on the balance of power in the physician-patient relationship. Many complex factors may contribute to obstetricians' viewpoint about maternal choice and elective caesarean birth, and attitudes among obstetrician appear to be changing.

Several studies have examined maternal choice of caesarean section from the obstetricians' point of view and found that physicians may play an important role in promoting elective caesarean delivery to individual women $(62,63)$. Physicians may push their patients toward requesting caesarean section with remarks that imply that it may be needed. The result of one European study exploring the attitudes of obstetricians showed that $>75 \%$ of German and British obstetricians accepted CBMD, as did even 22\% of obstetricians in the Netherlands where the caesarean rate was lowest (64). Wax and colleagues found that $8.3 \%$ of obstetricians surveyed cited convenience as a reason for giving birth by CBMD. Timing of caesarean deliveries is important to physicians. Lo has suggested that an increased rate of caesarean sections in the United States of America may occur in the last week of December so parents can take advantage of a tax deduction (65). Physicians have to juggle office visits, surgeries and deliveries during the day. Vaginal deliveries and emergency caesarean deliveries may keep a physician awake all night and result in significant fatigue. Planned elective caesarean deliveries can improve the schedule of the physician who schedules deliveries at their convenience (66). A caesarean section takes about 30 minutes compared to assisting with vaginal birth, 


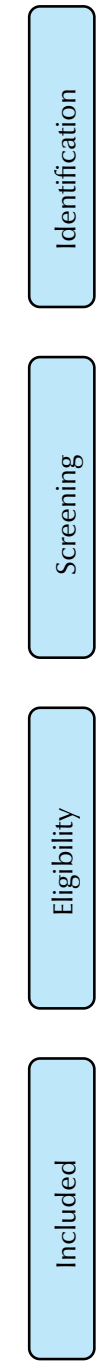

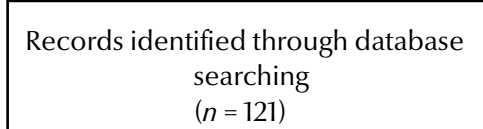

$(n=121)$
Additional records identified through other sources $(n=8)$

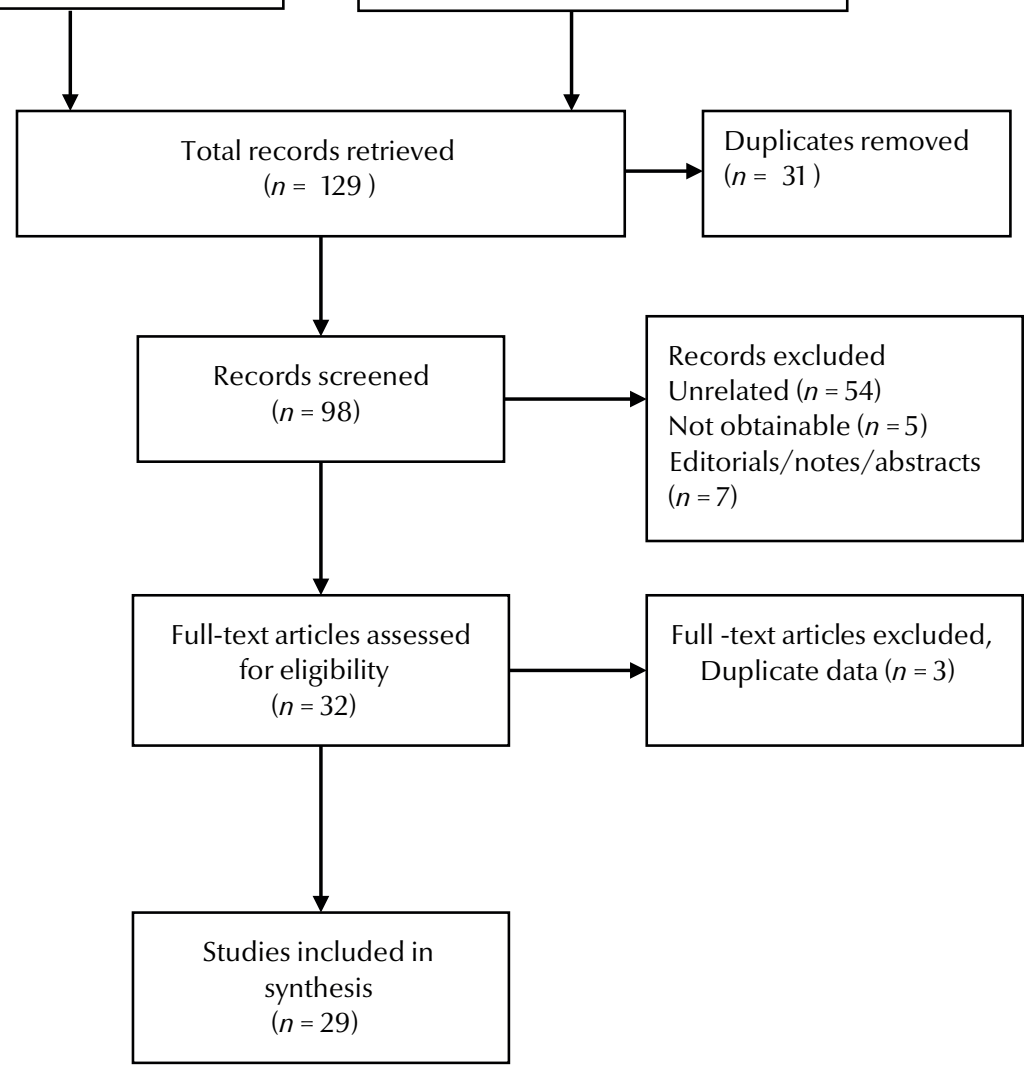

which may take up to 12 hours or more (67). In summary, physicians play an important role in a woman's decision to request a caesarean section. Convenience, physician fatigue and legal issues play a role in the attitude of physicians to encourage women to request a caesarean section.

\section{Study limitations}

There were some limitations to this review. First, the quality of studies that were analysed in this review was not examined. Second, some of the studies evaluated women's preferences and not actual demand for caesarean section. Therefore, the actual factor behind
CBMD cannot be inferred from those data.

\section{Conclusion}

This review may have implications for the health system, researchers and clinicians. The results suggest that the following factors may influence women's childbirth decisions: fear of vaginal birth pain, concern about infant safety, fear of urogenital trauma during vaginal birth, prior complicated vaginal childbirth, recommendation of family and friends, and opinion of healthcare providers (obstetricians or midwives). Considering the key reasons for caesarean section, providing effective interventions such as educational programmes to gain appropriate knowledge, enhancing the quality of vaginal birth services, and solutions to reduce the healthcare providers' recommendation for unnecessary and not-indicated caesarean sections are important.

\section{Acknowledgements}

Funding: This study was supported by Hormozgan University of Medical Sciences, Islamic Republic of Iran.

Competing interests: None declared. 
1. Caesarean Section. Clinical guideline [CG132]. London: National institute for Health and Care Excellence; 2012 (https:// www.nice.org.uk/guidance/cg132, accessed 5 April 2017).

2. Azami-Aghdash S, Ghojazadeh M, Dehdilani N, Mohammadi M, Asl Amin Abad R. Prevalence and causes of cesarean section in Iran: systematic review and meta-analysis. Iran J Pub Health. 2014;43(5):545-555.

3. Cesarean delivery on maternal request. NIH Consensus and State-of-the-Science Statements . 2006 27-29 Mar;23(1):1-29. Bethesda, MD: National Institutes of Health; 2006 (http:// consensus.nih.gov/2006/cesareanstatement.pdf, accessed 15 April 2017)

4. Ahmad-Nia S, Delavar B, Eini-Zinab H, Kazemipour S, Mehryar AH, Naghavi M. Caesarean section in the Islamic Republic of Iran: prevalence and some sociodemographic correlates. East Mediterr Health J. 2009 Nov-Dec;15(6):1389-98. PMID:20218129

5. Caesarean delivery on maternal request (CDMR). C-Obs 39. The Royal Australian and New Zealand College of Obstetricians and Gynaecologists; 2010 (https://www.ranzcog.edu. au/RANZCOG_SITE/media/DOCMAN-ARCHIVE/Caesarean\%20Delivery\%20on\%20Maternal\%20Request\%20(CObs\%2039)\%20Review\%20Nov13.pdf, accessed 5 April 2017).

6. Armson BA. Is planned caesarean childbirth a safe alternative? CMAJ. 2007 Feb 13;176(4):475-6. PMID:17296960

7. Lavender T, Hofmeyr GJ, Neilson JP, Kingdon C, Gyte GM. Caesarean section for non-medical reasons at term. Cochrane Database Syst Rev. 2012 Mar 14;3:CD004660. PMID:22419296

8. McCourt C, Weaver J, Statham H, Beake S, Gamble J, Creedy DK. Elective cesarean section and decision making: a critical review of the literature. Birth. 2007 Mar;34(1):65-79. PMID:17324181

9. Fenwick J, Staff L, Gamble J, Creedy DK, Bayes S. Why do women request caesarean section in a normal, healthy first pregnancy? Midwifery. 2010 Aug;26(4):394-400. PMID:19117644

10. Kingdon C, Baker L, Lavender T. Systematic review of nulliparous women's views of planned cesarean birth: the missing component in the debate about a term cephalic trial. Birth. 2006 Sep;33(3):229-37. PMID:16948723

11. Movahed M, Enayat H, Ghaffarinasab E, Alborzi S, Mozafari R. [Related factors to choose cesarean rather than normal delivery among Shirazian pregnant women]. J Fasa Univ Med Sci. 2012;2(2):78-83 (in Persian) (http://journal.fums.ac.ir/ article-1-49-en.html).

12. Naseh N, Khazaie T, Kianfar S, Dehghan R, Yoosefi S. [Prevalence of Cesarean and its complications in women referring to Vali-e-Asr hospital]. Modern Care. 2010;7(1-2):12-8 (in Persian) (http://moderncare.bums.ac.ir/browse.php?a id=92\&slc_lang=en\&sid=1\&ftxt=1)

13. Mohammad Pour Asl A, Rostami F, Torabi S. [Prevalence of cesarean section and it's demographic correlates in Tabriz. Med J Tabriz Univ Med Sci. 2006 Fall;28(3):101-5] (in Persian) (http:// en.journals.sid.ir/ViewPaper.aspx?ID=66018)

14. Lin $\mathrm{H}$, Xirasagar S. Maternal age and the likelihood of a maternal request for cesarean delivery: A 5-year populationbased study. Am J Obstet Gynecol. 2005 Mar;192(3):848-55. PMID:15746681

15. Byrom A. Advanced maternal age: A literature review. $\mathrm{Br} J$ Midwifery. 2004 Dec;12(12):779-83.

16. Benzies K, Tough S, Tofflemire K, Frick C, Faber A, NewburnCook C. Factors influencing women's decisions about timing of motherhood. J Obstet Gynecol Neonatal Nurs. 2006 SepOct;35(5):625-33. PMID:16958718
17. Suplee P, Dawley K, Bloch J. Tailoring peripartum nursing care for women of advanced maternal age. J Obstet Gynecol Neonatal Nurs. 2007 Nov-Dec;36(6):616-23. PMID:17973707

18. Bahonar A, Shaebani A, Aghajani M. [Determinants of cesarean and its trend in Damghan, Iran]. Iran J Epidemiol. 2010;6(1):33-8 (in Persian) (http://irje.tums.ac.ir/browse. php?a_id=91\&slc_lang=en\&sid=1\&ftxt=1)

19. Murray S. Relation between private health insurance and high rates of caesarean section in Chile: qualitative and quantitative study. BMJ. 2000 Dec 16;321(7275):1501-5. PMID:11118176

20. Loke A, Davies L, Li SF. Factors influencing the decision that women make on their mode of delivery: the Health BeliefModel BMC Health Serv Res. 2015 Jul 20;15:274. PMID:26188472

21. Negahban T, Ansari Jaberei A, Kazemi M. Preference method of delivery and it's relevant causes in view of pregnant women referring to public and private clinics in Rafsanjan City. J Rafsanjan Univ Med Sci. 2006;5(3):161-8 (in Persian) (http://journal. rums.ac.ir/browse.php?a_id=191\&slc_lang=en\&sid=1\&ftxt=1)

22. Aram $\mathrm{S}$, Allame Z, Zamani M, Yadegar $\mathrm{N}$. The relative frequency of the delivery method in the pregnant women referring to medical centers of Isfahan in 2002. Iran J Obstet Gynecol Infertil. 2002;8(4):74-9. [in Persian]

23. Faisal I, Matinnia N, Hejar AR, Khodakarami Z. Why do primigravida requests caesarean section in a normal pregnancy? A qualitative study in Iran. Midwifery. 2014 Feb;30(2):227-33. PMID:24055288

24. Akbari S, Ahmadi S. Analyzing the effective factors of choosing delivery method of the primiparous pregnant women attending to Khoramabad's Asalian hospital in 2014. Indian J Fundamental Appl Life Sci. 2014;4(3):656-63 (http://www.cibtech. org/J-LIFE-SCIENCES/PUBLICATIONS/2014/Vol-4-No-3/ JLS-098-102-SOHEILA-ANALYZING.pdf).

25. Abbaspoor Z, Moghaddam-Banaem L, Ahmadi F, Kazemnejad A. Women's fear of childbirth and its impact on selection of birth method. Payesh. 2014;13:575-87 (in Persian)

26. Jamshidi Manesh M, Jouybari L, Oskouie SF, Sanagoo A. How do women's decisions process to elective cesarean?: a qualitative study. Aust J Basic Appl Sci. 2011;5(6):210-5 (http:// en.cncr.iums.ac.ir/uploads/210-215.pdf).

27. Shahraki Sanavi F, Rakhshani F, Ansari-Moghaddam A, Edalatian M. Reasons for Elective Cesarean Section amongst Pregnant Women; A Qualitative Study. J Reprod Infertil. 2012 Oct;13(4):237-40. PMID:23926552

28. Ghooshchian S, Dehghani M, Khorsandi M, Farzad V. The role of fear of pain and related psychological variables in prediction of cesarean labor. Arak Med Univ J. 2011;14(3):4554 (in Persian) (http://amuj.arakmu.ac.ir/browse.php?a id $=798 \&$ slc_lang $=$ en \&sid=1\&ftxt=1)

29. Atghaei M, Nouhi A. Imagine the pain of labor and cesarean and vaginal delivery in pregnant women tends to be referred to clinics in Kerman University of Medical Sciences. Iran J Obstet Gynecol Infertil. 2010;14(7):44-50 (in Persian).

30. Mohammaditabar SH, Kiani A, Heidari M. The survey on tendencies of Primiparous women for selecting the mode of delivery. J Babol Univ Med Sci. 2009 Aug-Sep;11(3):54-9.

31. Moradan S. Evaluation of selection of route of delivery and its causes in patients referring to medical centers of Semnan from April till September. Iran J Obstet Gynecol Infertil. 2004;7(2):44-9 (in Persian).

32. Alavije Z, Shahry P, Kalhory M, Haghighizadeh M, Sharifirad G, Khorsandi M. Identification of factors related to elective cesarean labor: a theory-based study. Daneshvar. 2010;19(96):1-11 (in Persian) 
33. Poikkeus P, Saisto T, Unkila-Kallio L, Punamaki R, Repokari L, Vilska S, et al. Fear of childbirth and pregnancy-related anxiety in women conceiving with assisted reproduction. Obstet Gynecol. 2006 Jul;108:70-6. PMID:16816058

34. Waldenstrom U, Hildingsson I, Ryding E. Antenatal fear of childbirth and its association with subsequent caesarean section and experience of childbirth. BJOG. 2006 Jun;113(6):63846. PMID:16709206

35. Nerum H, Halvorsen L, Sorlie T, Oian P. Maternal request for cesarean section due to fear of birth: Can it be changed through crisis-oriented counseling? Birth. 2005 Sep;33(3):2218. PMID:16948722

36. Saisto T, Salmela AK, Nurmi JE, Kononen T, Halmesmaki E. A randomized controlled trial of intervention in fear of childbirth. Obstet Gynecol. 2001 Nov;98(5 Pt 1):820-6. PMID:11704175

37. Saisto T, Halmesmaki E. Fear of childbirth: A neglected dilemma. Acta Obstet Gynecol Scand. 2003 Mar;82(3):201-8. PMID:12694113

38. Hofberg K, Brockington I. Tokophobia: an unreasoning dread of childbirth. A series of 26 cases. Br J Psychiatry. 2000 Jan;176:83-5. PMID:10789333

39. Ip WY, Martin CR. Does confidence in labor predict the occurrence of postnatal depression? J Reprod Infant Psychol. 2008;26:270-1 (http://www.tandfonline.com/doi/ abs/10.1080/02646830802224440).

40. Tabande A, Kashani E. The prevalency of cesarean among employed educated women of medical science groups in Gorgan (2005). J Gorgan Univ Med Sci. 2007 Summer;9(2):67-70 (in Persian) (http://goums.ac.ir/journal/browse.php?a id $=265 \&$ slc_lang $=$ en \&sid $=1 \& \mathrm{ftxt}=1$ )

41. Lally JE, Murtagh MJ, Macphail S, Thomson R. More in hope than expectation: a systematic review of women's expectations and experience of pain relief in labor. BMC Med. 2008 Mar 14;6:7. PMID:18366632

42. Weaver J, Statham H, Richards M. Are there "unnecessary" cesarean sections? Perceptions of women and obstetricians about cesarean sections for nonclinical indications. Birth. 2007 Mar;34(1):32-41. PMID:17324176

43. Moeini B, Allahverdipour $\mathrm{H}$, Mahjoub H, Bashirian S. Assessing pregnant women's beliefs, behavioral intention and predictive factors for cesarean section in Hamadan. Iran J Obstet Gynecol Infertil. 2011 Aug-Sep;14(3):37-44 (in Persian).

44. Bagheri A, Masoodi Alavi N, Abbaszade F. Effective factors for choosing the delivery method among the pregnant women in Kashan. FEYZ. 2012;16(2):146-53.

45. Seyed Noori T, Jamshidi Aranaki F. Survey the relationship between knowledge and attitude of pregnant women requesting cesarean section referred to Rasht health centers and their choice reasons. J Guilan Univ Med Sci. 2006;15(59):75-84 (in Persian).

46. Bryant J, Porter M, Tracy SK, Sullivan EA. Caesarean birth: Consumption, safety, order, and good mothering. Soc Sci Med. 2007 Sep;65(6):1192-201. PMID:17590252

47. Cheung NF, Mander R, Cheng L, Chen VV, Yang XQ. Caesarean decision-making: negotiation between Chinese women and healthcare professionals. Evid Based Midwifery. 2006 Jul;4(1):24 (https://www.rcm.org.uk/learning-and-career/ learning-and-research/ebm-articles/caesarean-decisionmaking-negotiation-between).

48. 48. Weaver J, Stratham H. Wanting a caesarean section: the decision process. BrJ Midwifery. 2005;13(6):370-3.

49. Gezer A, Sximsek YO, Altinok TA. Elective cesarean section: evolution of obstetrician to technician. Birth. 2007 Dec;34(4):357-9. PMID:18021154
50. Kassak KM, Ali Abdallah AM. Opting for a cesarean: what determines the decision? Public Admin Manag. 2005;13(3):100-22.

51. Martin K. Giving birth like a girl. Gend Soc. 2003;17(1):54-72.

52. Hodnett ED, Gates S, Hofmeyr GJ, Sakala C, Weston J. Continuous support for women during childbirth. Cochrane Database Syst Rev. 2012 Feb 16;2:CD003766. PMID:21328263

53. Davari M, Maracy M, Ghorashi Z, Mokhtari M. The relationship between socioeconomic status and the prevalence of elective cesarean section in nulliparous women in Niknafs Teaching Centre, Rafsanjan, Iran. Womens Health Bull. 2014 Jul;1(2):e20044 (https://www.google.co.uk/url?sa=t\&rct=j\&q=\&esrc=s\&sour $c e=$ web $\&$ cd $=1 \&$ cad $=$ rja \&uact $=8 \& v e d=0$ ahUKEwjTseqsvY3TA hVJBMAKHeUrAVYQFgghMAA\&url=http\%3A\%2F\%2Fwome nshealthbulletin.com\%2F28880.pdf\&usg=AFQjCNHXV_Xoo6DRw73ZXqZ7GWUFN-Mng\&bvm=bv.151426398,d.d24),

54. BarleyK, Aylin P, Bottle A, Jarman B. Social class and elective Caesareans in the English NHS". BMJ. 2004 Jun 12;328(7453):1399. PMID:15191977

55. Zohreh F. Reza SG, Zahra F, Fatemeh P. Frequency of cesarean section and its related factors in Khomeinyshahr-Isfahan province 2005. Health System Res. 2011 Winter;6(4):786-93 (in Persian).

56. Mohammad Pour Asl A, Asgharian P, Rostami F, Azizi A, Akbari $\mathrm{H}$. Investigating the choice of delivery method type and its related factors in pregnant women in Maragheh. Knowl Health 2009 Spring; 4(1):36-39 (in Persian).

57. Mobaraki A. Zadehbagheri G, Zandi Ghashghaie KA. Prevalence of cesarean section and the related causes in Yasuj City in 2003. Armaghan-e-Danesh. 2005;10(3):67-73

58. Sharghi A, Kamran A, Sharifirad GR. Assessing the factors influencing delivery method selection in primiparous pregnant women referred to health centers in Ardabil. Med J Hormozghan. 2011 Fall;15(3):234-42 (in Persian).

59. Shareat M, Majlasei F, Azarei S, Mahmodei M. Cesarean section rate and its determinants in maternity hospitals in Tehran. Payesh. 2002;1(3):5-10 (in Persian).

60. Alimohamadian M, Shariat M, Mahmoodi M, Ramezanzadeh F. The survey of impact of pregnant women's request in selected cesarean. Payesh. 2003;2(2):133-9 (in Persian).

61. Wax J, Cartin A, Pinette M, Blackstone J. Patient choice cesarean - the Maine experience. Birth. 2005 Sep;32(3):203-6. PMID:16128974

62. Gonen R, Tamir A, Degani S. Obstetricians' opinions regarding patient choice in cesarean delivery. Obstet Gynecol. 2002 Apr;99(4):577-80. PMID:12039114

63. Mayberry L. Nursing implications of the $2006 \mathrm{NIH}$ State of the Science Conference Statement: cesarean delivery on maternal request. MCN Am J Matern Child Nurs . 2006 SepOct;31(5):286-9.

64. Habiba M, Kaminski M, Da Frè M, Marsal K, Bleker O, Librero J, et al. Caesarean section on request: a comparison of obstetricians' attitudes in eight European countries. BJOG. 2006 Jun;113(6):647-56. PMID:16709207

65. Lo J. Patients' attitudes vs. physicians' determination: Implications for cesarean sections. Soc Sci Med. 2003 Jul;57(1):91. PMID:12753818

66. Brown HS 3rd. Physician demand for leisure: Implications for cesarean section rates. J Health Econ. 1996 Apr;15(2):233. PMID:10159111

67. Penna L, Arulkumaran S. Cesarean section for non-medical reasons. Int J Gynaecol Obstet. 2003 Sep;82(3):399-409. 